\title{
The Effect of Neem, Citronella, Castor Oil, and Their Mixtures against Crocidolomia pavonana F. (Lepidoptera: Crambidae)
}

\author{
Leni Maryani ${ }^{1}$, Danar Dono ${ }^{2 *}$, Endah Yulia $^{2}$ \\ ${ }^{1}$ Alumny of Agrotechnology study program, Agriculture Faculty, Universitas Padjadjaran, Jatinangor, West Java, Indonesia, \\ 45363 \\ ${ }^{2}$ Department of Plant Pests and Diseases, Agriculture Faculty, Universitas Padjadjaran, Jatinangor, West Java, Indonesia, \\ 45363 \\ *Corresponding Author: danar.dono@unpad.ac.id
}

Received October 28, 2019; revised November 26, 2019; accepted December 17, 2019

\begin{abstract}
Cabbage-heart caterpillar, Crocidolomia pavonana F. (Lepidoptera: Crambidae), is one of the important pests in Brassicaceae family. Alternative control for cabbage-heart caterpillar that can be used is insecticide made from plant extracts. Neem, cirtonella and jatropha oil are reported to have an insecticidal properties. This study aimed to determine the effect of singgle or combination of neem, citronella, and castor oil to against $C$. pavonana larvae and to obtain the most effective ratio and concentration of oil combinations. The experimental method used in this research was Randomized Block Design with 41 treatments, i.e. control, single neem, citronella, castor oil and its combination each tested at concentration of $1 \% ; 0,5 \% ; 0,25 \%$; and $0,1 \%$. Each treatment was replicated 3 times. The results of this experiment showed that single oil or combination of neem, citronella and castor oil at consentration of $1 \%$ and $0,5 \%$ caused $100 \%$ larvae mortality, 1:3:2 ratio at $1 \%$ concentration was able to reduce food consumption, $3: 2: 1$ ratio at $0,25 \%$ concentration was inhibit larvae development and reduce the weight of pupae, and 3:1:2 ratio at $0,5 \%$ concentration can reduce the weight of larvae.
\end{abstract}

Keywords: Toxicity, Azadirachta indica, Cymbopogon nardus, Riccinus communis, Crocidolomia pavonana

\section{ABSTRAK}

Pengaruh Minyak Mimba, Sitronella, Jarak dan Campuran Ketiganya terhadap Crocidolomia pavonana F. (Lepidoptera: Crambidae)

Ulat crop kubis, Crocidolomia pavonana F. (Lepidoptera: Crambidae), merupakan salah satu hama penting pada tanaman Brassicae. Salah satu alternatif pengendalian ulat krop kubis yang dapat dilakukan yaitu dengan menggunakan insektisida yang dibuat dari ekstrak tumbuhan. Minyak mimba, serai wangi, dan jarak dilaporkan memiliki sifat sebagai insektisida. Penelitian ini bertujuan untuk mengetahui pengaruh tunggal atau kombinasi minyak mimba, serai wangi, dan jarak terhadap larva $C$. pavonana. Metode yang digunakan adalah metode eksperimen dengan Rancangan Acak Kelompok yang terdiri atas empat puluh satu perlakuan, yaitu kontrol, minyak mimba, serai wangi, jarak dan kombinasi ketiganya yang diuji pada konsentrasi $1 \% ; 0,5 \% ; 0,25 \%$; dan $0,1 \%$. Setiap perlakuan diulang sebanyak 3 kali. Hasil penelitian menunjukkan bahwa perlakuan minyak mimba, serai wangi, dan jarak secara kombinasi maupun tunggal pada konsentrasi $1 \%$ dan $0,5 \%$ menyebabkan mortalitas $100 \%$, perlakuan kombinasi rasio 1:3:2 pada konsentrasi $1 \%$ mampu menekan konsumsi pakan, rasio 3:2:1 pada konsentrasi 0,25\% mampu menghambat perkembangan larva dan menurunkan bobot pupa, serta rasio 3:1:2 pada konsentrasi $0,5 \%$ mampu menurunkan bobot larva.

Kata kunci: Toksisitas, Azadirachta indica, Cymbopogon nardus, Riccinus communis, Crocidolomia pavonana

\section{PENDAHULUAN}

Penggunaan insektisida secara berlebihan dan tidak bijaksana dapat menimbulkan berbagai dampak merugikan di antaranya berkurangnya diversitas organisme dalam lingkungan serta gangguan kesehatan manusia (Mahmood et al., 2016). Penggunaan pestisida yang berlebihan juga mengakibatkan resistensi dan resurjensi hama, serta terbunuhnya musuh alami, (Dono et al., 2010, dan 2014). Berdasarkan hal tersebut maka perlu dilakukan pengembangan insektisida nabati untuk meminimalkan penggunaan insektisida sintetik.

Beberapa ekstrak tumbuhan seperti mimba (Azadirachta indica L.), serai wangi (Cymbopogon nardus L. Rendle), dan jarak (Riccinus communis L.) dilaporkan bersifat insektisida. Minyak mimba dilaporkan bersifat insektisida, mengganggu pertumbuhan dan perkembangan larva (Ismann et al. 1990; Subiyakto, 2009). Perlakuan ekstrak metanol mimba pada larva Plutella xylostella menghasilkan nilai konsentrasi letal $\left(\mathrm{LC}_{50}\right)$ sebesar 0,61\% (Sharma et al., 2014). Suyanto \& Manan (2011) melaporkan bahwa ekstrak air biji mimba pada konsentrasi 2,5\% dapat menekan peletakan telur Crocidolomia pavonana sebesar $84,8 \%$ dan pada konsentrasi $5 \%$ menekan penetasan telur C. pavonana sebesar $95 \%$. Syahputra (2013) melaporkan bahwa ekstrak biji $A$, indica memiliki nilai $\mathrm{LC}_{50}$ sebesar $0,24 \%$ terhadap larva C. pavonana.

Minyak serei dilaporkan bersifat toksik terhadap beberapa sepesies serangga. Minyak serai wangi diketahui mampu mengakibatkan mortalitas 
telur dan larva serta menghambat imago C. pavonana untuk meletakkan telur. Aplikasi minyak serai wangi dengan konsentrasi $0,5 \%$ pada daun pakan mengakibatkan mortalitas lebih dari $90 \%$, sedangkan aplikasi langsung pada larva mengakibatkan mortalitas $28 \%$ (Balfas \& Mardiningsih, 2016). Pengujian serai wangi terhadap larva Plutella xylostella menghasilkan nilai toksisitas $\mathrm{LC}_{50}$ sebesar $0,63 \%$ (Zahro dkk., 2016). Minyak serai wangi pada konsentrasi $0,3-0,5 \%$ melalui pengujian perlakuan daun pakan terhadap larva Helicoverpa armigera dapat menurunkan laju pertumbuhan relatif, efisiensi konversi makanan yang dimakan, serta menghambat aktivitas makan larva $H$. armigera sebesar 50\% (Hasyim et al., 2010). Pinheiro et al. (2013) melaporkan bahwa minyak serei pada konsentrasi $1 \%$ (w $\mathrm{v}^{-1}$ ) mengakibatkan kematian Myzus persicae sebesar $96,9 \%$.

Minyak jarak (Riccinus communis) pada konsentrasi 5\% melalui pengujian kontak dan uji makan terhadap larva Plutella xylostella instar III berturut-turut mengakibatkan kematian serangga uji sebesar 82,19\% dan 89,58\% (Kodjo et al. 2011). Hasil penelitian Ramos-Lopes et al. (2010) bahwa minyak jarak pada konsentrasi 1,6\% mengakibatkan kematian larva Spodoptera frugiperda sebesar $100 \%$.

Insektisida nabati dapat digunakan dalam bentuk tunggal maupun campuran. Pencampuran insektisida yang sinergi akan lebih efisien apabila dibandingkan dengan penggunaan ekstrak tunggal dikarenakan dalam campuran kedua komponen tersebut digunakan konsentrasi yang lebih rendah (Dadang \& Prijono, 2008). Beberapa campuran insektisida sudah dibuktikan keefektifannya melalui berbagai penelitian. Campuran ekstrak sirih hutan (Pipe Aduncum) dengan ekstrak daun Tephrosia voogelly dilaporkan bersifat sinergis dalam mengakibatkan kematian ulat krop kubis C. pavonana (Nailufar \& Prijono, 2017). Ekstrak P. aduncum juga dilaporkan bersifat sinergis bila dicampurkan dengan ekstrak buah rerak (Sapindus rarak) (Syahroni \& Prijono, 2013). Namun penelitian yang menggunakan campuran tiga jenis minyak tumbuhan mimba, serai wangi dan jarak belum pernah dilakukan. Penelitian ini bertujuan untuk mengetahui pengaruh tunggal dan kombinasi ketiga jenis minyak tersebut pada berbagai perbandingan terhadap ulat krop kubis $C$. pavonana.

\section{BAHAN DAN METODE}

Percobaan dilaksanakan di laboratorium Pestisida dan Toksikologi Lingkungan, Departemen Hama dan Penyakit Tumbuhan, Fakultas Pertanian Universitas Padjadjaran yang berlangsung mulai Mei sampai Agustus 2019.

Minyak mimba diperoleh dari pengepresan biji mimba yang berasal dari Situbondo, Jawa Timur. Biji dipanen Januari 2018 kemudian dikupas kulit buahnya lalu dikering anginkan. Biji kering angin dipress menggunakan alat pengepress panas untuk memperoleh minyak biji mimba. Minyak jarak dan minyak serai wangi diperoleh dari toko dan distributor bahan kimia.

Percobaan dalam penelitian ini terdiri dari 41 perlakuan yaitu kontrol, minyak mimba, serai wangi, dan jarak serta kombinasinya. Kombinasi minyak nabati dibuat dengan cara mencampurkan minyak mimba : serai wangi : jarak sesuai rasio yaitu $1: 1: 1$; $1: 2: 3 ; 1: 3: 2 ; 2: 3: 1 ; 2: 1: 3 ; 3: 2: 1$. Setiap kombinasi campuran minyak nabati dan minyak tunggalnya diuji pada konsentrasi $1 \%, 0.5 \%, 0.25 \%$, dan $0.25 \%$. Sebagai pelarut pengencer digunakan akuades yang mengandung $0,5 \%\left(5 \mathrm{ml}\right.$. $\left.\mathrm{L}^{-1}\right)$ campuran Tween 80 : Span 80 dengan perbandingan $4: 1$. Pembuatan larutan minyak nabati $1 \%$ dilakukan dengan cara $1 \mathrm{ml}$ minyak nabari dimasukkan ke dalam labu ukur 100 $\mathrm{ml}$ menggunakan pipet. Ke dalam labu ukur tersebut kemudian dimasukkan akuades yang telah mengandung pengemulsi secara bertahap-dikocokhingga volume mencapai $100 \mathrm{ml}$. Perlakuan konsentrasi dan jenis perbandingan minyak nabati lainnya dibuat dengan cara yang sama. Pada perlakuan kontrol digunakan larutan akuades dan pengemulsi (Tween 80 : Span $80=4: 1$ ) tanpa minyak nabati.

Pengujian dilakukan dengan menggunakan metode celup daun pakan. Daun pakan brokoli dipotong dengan ukuran $4 \mathrm{~cm} \times 4 \mathrm{~cm}$. Daun dicelupkan kedalam larutan minyak nabati sesuai jenis perlakuan selama 10 detik, lalu daun dikering anginkan. Setelah kering daun kemudian dimasukkan kedalam cawan petri. Ke dalam setiap cawan petri dimasukkan larva $C$. pavonana instar II sebanyak 10 ekor. Pemberian pakan daun dengan perlakuan minyak nabati pada larva uji dilakukan selama 48 jam. Selanjutnya pemberian pakan menggunakan daun segar tanpa perlakuan hingga larva berkembang menjadi pupa kemudian imago. Pengamatan dilakukan setiap hari dengan peubah yang diamati yaitu:

\section{Mortalitas Larva $C$. pavonana}

Pengamatan mortalitas larva dilakukan setiap hari sejak $1 \mathrm{HSP}$ hingga $20 \mathrm{HSP}$. Mortalitas larva $C$. pavonana dihitung dengan rumus :

$$
\text { Mortalitas (\%) }=\frac{\text { Jumlah C.pavonana yang mati }}{\text { Jumlah C.pavonana yang diuji }} \times 100 \%
$$

\section{Konsumsi Pakan Larva C. pavonana}

Daun pakan yang dikonsumsi oleh larva uji diukur berdasarkan bobot kering pakan. Langkah pertama yaitu dibuatkan faktor pengoreksi dengan cara tiga potongan daun berukuran $4 \times 4 \mathrm{~cm}$ masing masing ditimbang beratnya, kemudian daun tersebut dikeringkan dengan cara dioven oven selama 48 jam dengan temperatur $90^{\circ} \mathrm{C}$. Masing-masing daun yang telah kering tersebut ditimbang hingga diperoleh bobot kering. Daun sampel yang telah kering dimasukkan ke dalam rumus sebagai berikut: 


$$
\text { Kadar biomassa }(\%)=\frac{\mathrm{BK}^{\prime}}{\mathrm{BB}^{\prime}} \times 100 \%
$$

Keterangan:

$\mathrm{BK}^{\prime}=$ Bobot kering sampel $(\mathrm{g})$

$\mathrm{BB}^{\prime}=$ Bobot basah sampel $(\mathrm{g})$

$\%$ Kadar biomassa (sebagai penduga bobot kering awal pakan)

Pengamatan konsumsi pakan dilakukan pada 48 jam setelah perlakuan. Bobot kering awal pakan diperoleh berdasarkan hasil perkalian bobot basah awal dari dengan kadar biomassa rata-rata bobot sampel daun sebagai faktor koreksi. Bobot basah awal daun pakan diperoleh dari hasil penimbangan daun pakan.

Bobot basah pakan yang diuji juga ditimbang terlebih dahulu sebelum diberi perlakuan sehingga dapat diperoleh bobot kering awal dengan rumus sebagai berikut:

Keterangan

$$
\mathrm{BKa}=\mathrm{BBa} \times \mathrm{x} \text { Kadar biomassa }
$$

$\mathrm{BBa}^{\prime}=$ Bobot basah awal $(\mathrm{g})$

$\mathrm{BKa}^{\prime}=$ Bobot kering awal $(\mathrm{g})$

Setelah pemberian periode makan selama 48 jam. Sisa daun yang telah dikonsumsi kemudian dioven selama 48 jam pada suhu $90^{\circ} \mathrm{C}$ kemudian ditimbang untuk memperoleh bobot kering akhir (BKak). Pengamatan konsumsi pakan larva $C$. pavonana dapat menunjukkan efek antifeedant dari kombinasi ekstrak mimba, serai wangi, dan jarak. Bobot konsumsi pakan dihitung dengan rumus sebagai berikut:

$$
\text { Konsumsi pakan }=\frac{\mathrm{BKa}-\mathrm{BKak}}{\mathrm{BKa}} \times 100 \%
$$

Keterangan:

BKak= Bobot kering akhir $(\mathrm{g})$

\section{Lama Perkembangan Larva $C$. pavonana}

Pengamatan lama perkembangan larva $C$. pavonana dilakukan dengan menghitung waktu yang dibutuhkan larva selama proses pergantian instar ke instar berikutnya yang dicirikan dengan ditemukannya kutikula lama yang telah dilepaskan (eksuvia). Pengamatan dilakukan dengan interval 24 jam hingga larva berkembang menjadi pupa.

\section{Bobot Larva Instar IV, Pembentukan Pupa dan Bobot Pupa $C$. pavonana}

Bobot larva instar IV ditimbang pada hari ke2 setelah larva yang bertahan hidup berkembang menjadi instar IV.

\section{HASIL DAN PEMBAHASAN}

\section{Pengaruh Jenis Minyak Nabati dan Campurannya terhadap Mortalitas Larva $C$. pavonana}

Perlakuan minyak mimba, serai wangi, dan jarak secara tunggal maupun kombinasi menyebabkan mortalitas serta gangguan terhadap aktivitas larva $C$. pavonana. Larva yang mati menunjukkan ciri-ciri tubuh kaku, berwarna kecoklatan, dan mengering (Gambar 1). Sementara itu larva yang bertahan hidup mengalami pertumbuhan dan perkembangan yang lambat, tidak aktif makan, dan tidak aktif bergerak. Aktivitas abnormal tersebut diduga diakibatkan oleh kerja bahan aktif yang terkandung dalam masingmasing minyak nabati.

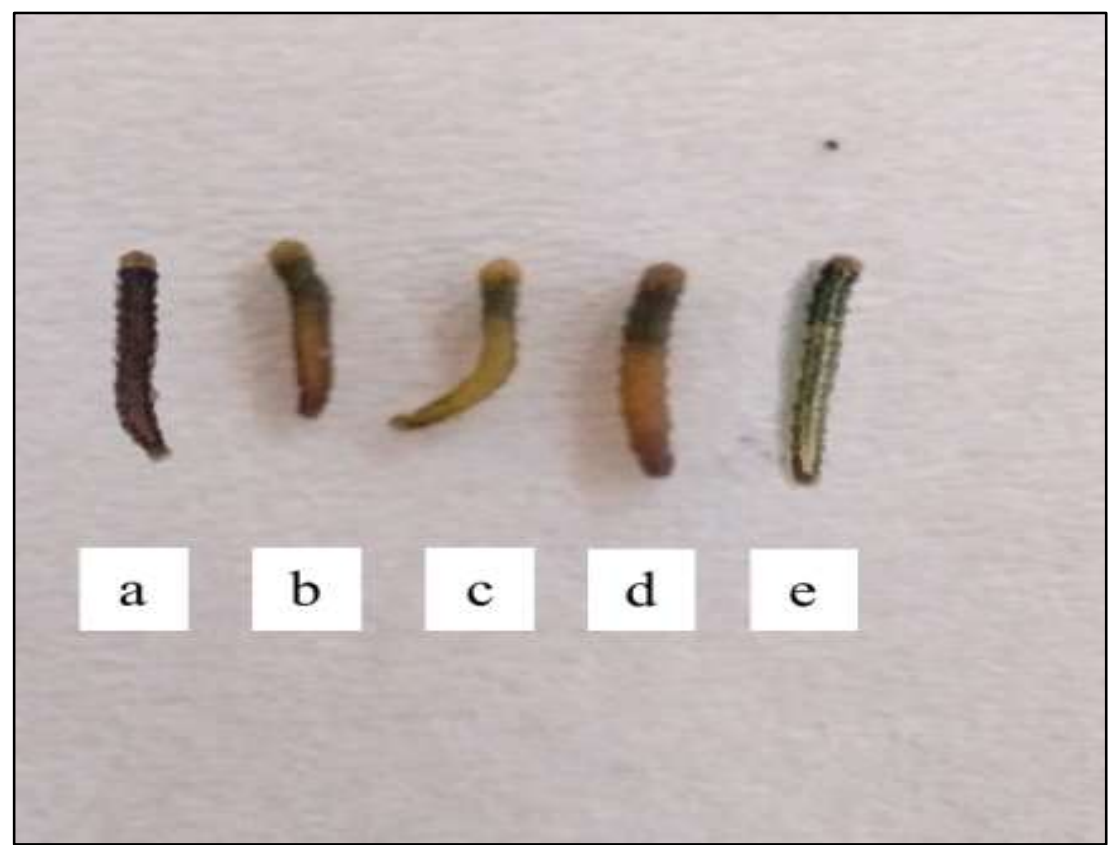

Gambar 1. Pengaruh perlakuan minyak nabati terhadap mortalitas larva. (a) Kombinasi 3:2:1, (b) Mimba tunggal, (c) Serai wangi, (d) Jarak, (e) Larva hidup pada perlakuan control. 
Hasil percobaan menunjukkan bahwa perlakuan minyak mimba, serai wangi, dan jarak secara kombinasi maupun tunggal pada konsentrasi 0,$1 ; 0,25 ; 0,5$ dan $1,0 \%$ mengakibatkan kematian larva C. pavonana dengan memperlihatkan kecenderungan semakin tinggi konsentrasi kematian serangga semakin cepat dibandingkan perlakuan konsentrasi yang lebih rendah (Gambar 2). Perlakuan kombinasi mimba : serai wangi : jarak dengan rasio 3:2:1 dan perlakuan minyak mimba tunggal mencapai mortalitas $100 \%$ pada setiap konsentrasi yang diujikan. Kematian serangga uji diduga disebabkan oleh senyawa azadirakhtin yang terkandung di dalam minyak mimba yang kemungkinan memiliki sifat lebih toksik apabila dibandingkan dengan bahan aktif minyak serai wangi dan jarak, dengan demikian perlakuan kombinasi dengan rasio 3:2:1 dan perlakuan minyak mimba secara tunggal bisa mematikan seluruh larva uji pada setiap konsentrasi.

Mortalitas $100 \%$ pada konsentrasi $0,5 \%$ dengan rasio 3:2:1 bahkan telah dicapai pada 1 HSP. Walaupun demikian, seringkali hama tidak langsung mati setelah aplikasi dan biasanya membutuhkan waktu 4-5 hari untuk mati (Indiati \& Marwoto, 2008).

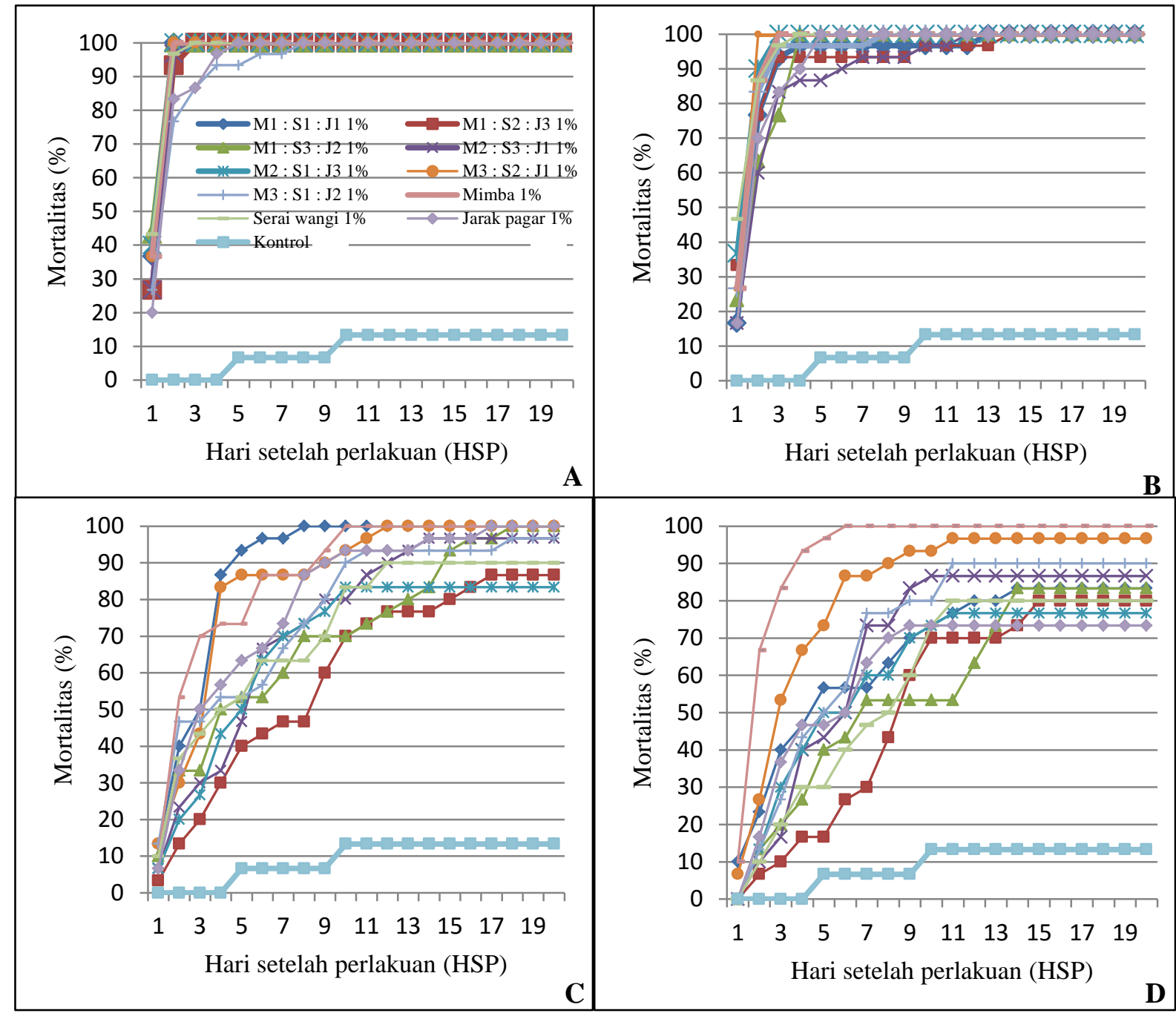

Gambar 2. Mortalitas kumulatif C. pavonana pada berbagai perlakuan minyak mimba, sitronella, jarak dan campurannya dengan konsentrasi $1,0 \%$ (A), 0,5\% (B), 0,25\% (C), dan $0,1 \%$ (D).

Mortalitas pada larva uji diduga juga disebabkan oleh adanya kandungan risin pada minyak jarak, serta sitronella pada minyak serai. Senyawa aktif risin dilaporkan sebagai penghambat pembentukan protein dalam (Frigerio \& Roberts 1998). Serangga yang terpapar menunjukkan larva yang lemah dan cenderung menjauhi pakan. Racun perut menyebabkan penurunan penyerapan nutrisi sehingga berkontribusi pada kematian larva uji (Ahdiyah \& Purwani, 2015).

\section{Pengaruh Jenis Minyak Nabati dan Campurannya terhadap Konsumsi Pakan Larva $\boldsymbol{C}$. pavonana}

Perlakuan minyak mimba, serai wangi, dan jarak secara kombinasi maupun tunggal yang diberikan mampu menurunkan konsumsi pakan $C$. pavonana apabila dibandingkan dengan kontrol. Rata- 
rata konsumsi pakan pada perlakuan kontrol dapat mencapai 68,93\% (Tabel 1). Perlakuan yang menyebabkan konsumsi pakan paling rendah yaitu perlakuan kombinasi minyak mimba: serai wangi: jarak rasio 1:3:2 dengan konsentrasi 1\% dengan ratarata konsumsi pakan sebesar 10,85\%. Walaupun secara tunggal minyak mimba dan minyak serei wangi dilaporkan mengakibatkan penurunan aktivitas makan (Hasyim et al., 2010; Isman et al., 1990; Pinheiro \& Quintela (2010), namun perlakuan dengan campurannya menunjukkan pengaruh penghambatan aktivitas makan tersebut menjadi lebih kuat.
Perlakuan kombinasi dengan rasio minyak serai wangi yang lebih banyak dibandingkan minyak lainnya menyebabkan konsumsi pakan yang rendah. Minyak serai wangi dilaporkan memiliki aktivitas sebagai penolak serangga yang kuat (Isman 2006). Hasil percobaan Fujiarista (2019) menunjukkan bahwa campuran minyak mimba dan serai wangi dengan perbandingan 1:3 pada konsentrasi 1\% mengakibatkan konsumsi pakan paling rendah yaitu mencapai $2,33 \%$.

Tabel 1. Rata-rata konsumsi pakan larva C. pavonana pada 2 HSP

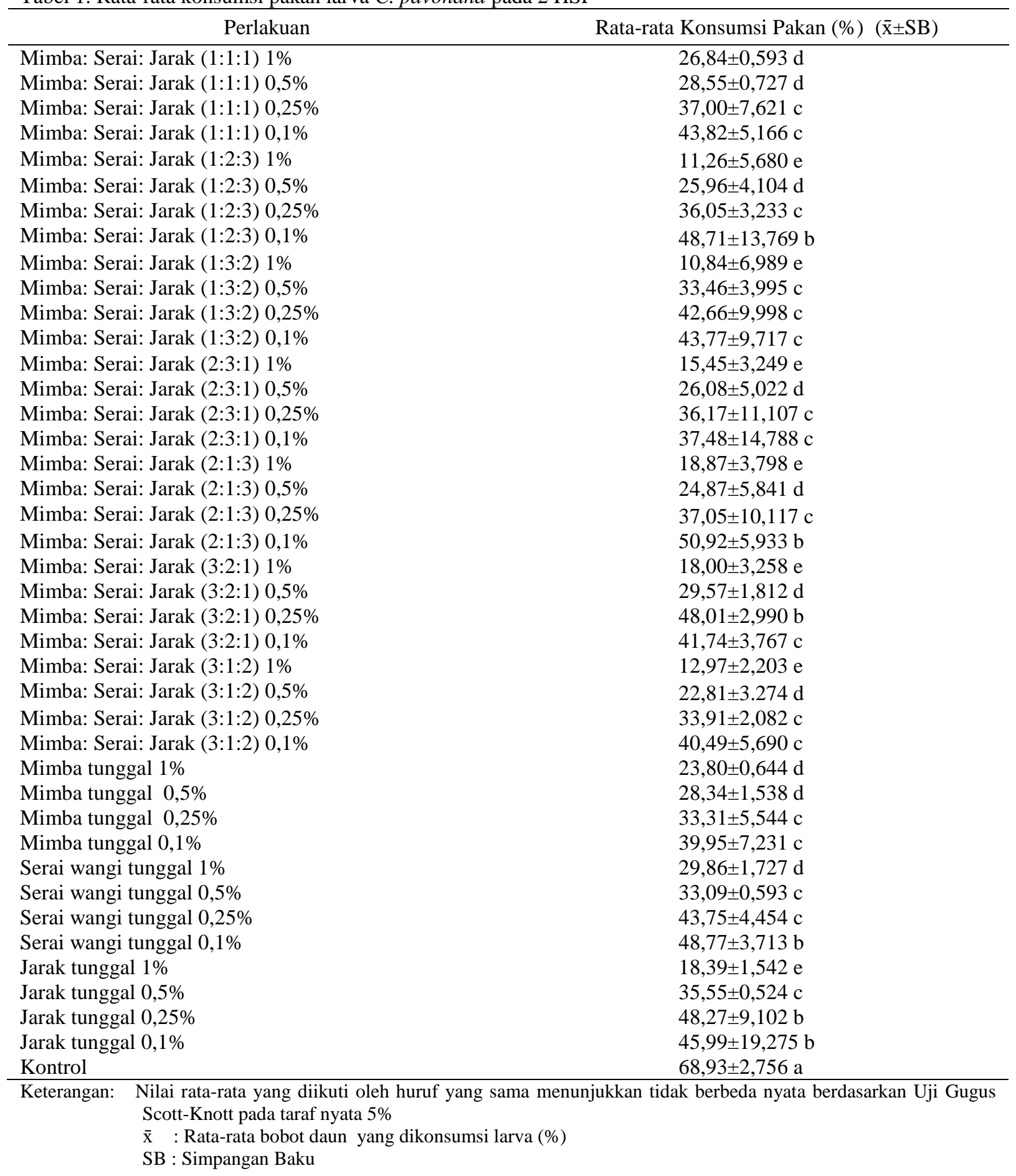


Pada perlakuan kontrol, larva bersembunyi dibalik daun dan memakannya hingga menyisakan epidermisnya saja. Sementara itu pada perlakuan yang diberi kombinasi minyak ataupun minyak tunggal, larva cenderung menjauhi pakan yang mengindikasikan adanya penolakan makan. Hal ini sejalan dengan pernyataan Atkins (1980) dan Widayani dkk. (2018), bahwa serangga akan melakukan proses pengenalan terhadap makanannya, jika ada bahan yang akan merugikan maka serangga tidak memakannya dan akan pergi meninggalkan makanan tersebut.

Kandungan azadirakhtin pada minyak mimba mengakibatkan gangguan pada reseptor kimia pada bagian mulut serangga yang mengganggu persepsi rangsangan untuk makan (Ahadian, 2010). Minyak jarak diketahui mengandung saponin yang merupakan senyawa antifidan. Senyawa antifidan tidak mematikan secara langsung namun dapat menghambat aktivitas makan (feeding inhibition), bersifat suppressant (menekan aktivitas menggigit), dan detterent (mencegah serangga terus makan) (Sayuthi dkk., 2014). Masuknya senyawa aktif ini ke dalam tubuh serangga pada akhirnya akan menyebabkan terganggunya aktivitas makan sehingga asupan nutrisi yang dibutuhkan oleh serangga menjadi berkurang (Dono dkk., 2010).

Menurunnya jumlah pakan yang dikonsumsi juga dapat disebabkan oleh senyawa alelokimia dalam serai wangi yang bersifat toksik. Sebagaimana penelitian yang telah dilakukan oleh Sahayaraj et al., (2008) bahwa minyak serai tidak mempengaruhi jumlah pakan yang dikonsumsi secara langsung, namun gangguan pada proses fisiologi dalam tubuh larva mengakibatkan respons kompensasi nutrisi yang dikonsumsi untuk menetralisir racun dalam tubuh. Sebagian energi yang seharusnya digunakan untuk proses pertumbuhan dan perkembangan dialokasikan untuk menetralkan racun tersebut. Proses ini pada akhirnya akan menyebabkan hambatan pertumbuhan dan pada akhirnya dapat mengakibatkan kematian serangga uji.

\section{Pengaruh Jenis Minyak Nabati dan Campurannya terhadap Waktu Perkembangan Larva $C$. pavonana}

Pemberian perlakuan minyak mimba, serai wangi, dan jarak secara kombinasi maupun tunggal berpengaruh terhadap lama perkembangan larva $C$. pavonana. Adanya perlakuan minyak menyebabkan waktu perkembangan larva dari instar II hingga menjadi pupa mengalami keterlambatan 1-8 hari apabila dibandingkan dengan kontrol (Tabel 2). Hal tersebut sejalan dengan percobaan Wiranda (2019) bahwa perlakuan campuran minyak mimba dan minyak jarak dengan perbandingan 1:3 dengan konsentrasi $1 \%$ menghambat perkembangan larva instar II ke IV hingga 8 hari.

Terhambatnya perkembangan larva $C$. pavonana diduga disebabkan oleh senyawa bioakatif azadirakhtin yang terkandung dalam minyak mimba. Azadirakhtin diketahui menyebabkan gangguan terhadap hormon ecdyson yang berperan dalam proses perkembangan serangga. Gangguan pada hormon ecdysone tersebut mempengaruhi pergantian instar, pembentukan kaki semu dan pembentukan pupa (Cheng et al., 2014).

\section{Pengaruh Jenis Minyak Nabati dan Campurannya terhadap Bobot Larva, Pupasi, dan Bobot Pupa $C$. pavonana}

Perlakuan kombinasi minyak mimba: serai wangi: jarak pada rasio 3:1:2 dengan konsentrasi $0,5 \%$ mengakibatkan bobot rata-rata larva terendah yaitu 0,004 gram, sedangkan larva kontrol memiliki berat rata-rata lebih tinggi yaitu 0,045 g. (Tabel 3). Larva yang normal memiliki tubuh yang cukup besar, yaitu sekitar 1-1,5 cm dan berwarna hijau muda hingga hijau tua, sedangkan larva yang mendapat perlakuan ekstrak tunggal maupun campurannya memiliki ukuran tubuh yang lebih kecil, dan berwarna lebih pucat atau terlihat kekuningan.

Rendahnya bobot larva diduga disebabkan oleh rendahnya konsumsi pakan akibat efek antifeedant pada berbagai minyak yang digunakan. Hal ini dikuatkan dengan pernyataan Tukimin dkk., (2010) bahwa gejala larva yang tidak mau mengonsumsi pakan bisa disebabkan oleh beberapa faktor, diantaranya makanan yang dikonsumsi, gangguan pencernaan, dan kerusakan saraf dalam sel neurosekretori yang mengakibatkan larva kekurangan nutrisi sehingga memiliki bobot yang rendah.

Risin sebagai salah satu kandungan minyak jarak bekerja menghambat pembentukan protein dalam sel sehingga tanpa protein akhirnya sel akan mengalami kematian (Frigerio \& Roberts 1998) sehingga dapat mengakibatkan gangguan pertumbuhan dan metamorphosis serangga. Wei et al. (2004) menyatakan bahwa toksisitas ricin ditentukan oleh rantai lektin dari struktur molekulnya. ShahidiNoghabi et al. (2009) menyebutkan bahwa risin berperan sebagai anti serangga.

Rata-rata bobot pupa pada perlakuan kontrol yaitu $0.051 \mathrm{~g}$, sedangkan bobot pupa paling rendah terdapat pada perlakuan kombinasi dengan rasio 3:1:2 pada konsentrasi $0,1 \%$ (Tabel 3). Hasil pengamatan menunjukkan terdapat larva yang gagal membentuk pupa. Larva yang gagal membentuk pupa terlihat memiliki bentuk yang abnormal. ukuran tubuhnya kecil dan ada yang sudah memiliki bentuk menyerupai imago namun tidak sempurna (Gambar 3a). Larva yang gagal membentuk pupa berubah warna menjadi kehitaman dan mati dalam gumpalan tanah. Beberapa pupa memiliki bentuk yang abnormal seperti berukuran kecil, berwarna kehitaman dan mengerut (Gambar 3b). Bentuk pupa yang abnormal juga memiliki bobot pupa yang rendah. Gangguan pada hormon ecdysone tersebut mempengaruhi pembentukan kaki semu (proleg), perubahan instar, dan pembentukan pupa (Cheng et al., 2014). 
Walau berhasil membentuk pupa, tidak semua pupa berhasil berubah menjadi imago. Pupa yang tidak berubah menjadi imago dinyatakan gagal membentuk imago. Beberapa imago yang berhasil muncul memiliki bentuk yang abnormal. Imago abnormal memiliki bentuk sayap yang keriting sehingga tidak mengembang dengan sempurna, serta beberapa memiliki abdomen yang mengertu (Gambar 3d).

Kegagalan pembentukan pupa, kegagalan perubahan pupa menjadi imago, serta bentuk abnormal yang terjadi pada pupa dan imago $C$. pavonana yang telah diberi perlakuan diduga berkaitan erat dengan adanya gangguan hormonal diantaranya hormon ecdyson. Apabila hormon ecdyson terganggu maka pembentukan pupa dan imago juga akan terganggu. Gangguan pada hormon ecdysone tersebut mempengaruhi metamorfosa serangga misalnya pembentukan kaki semu (proleg), pergantian instar, dan pembentukan pupa (Cheng et al., 2014: Samsudin, 2011).

Tabel 2. Rata-rata perkembangan larva C. pavonana (hari)

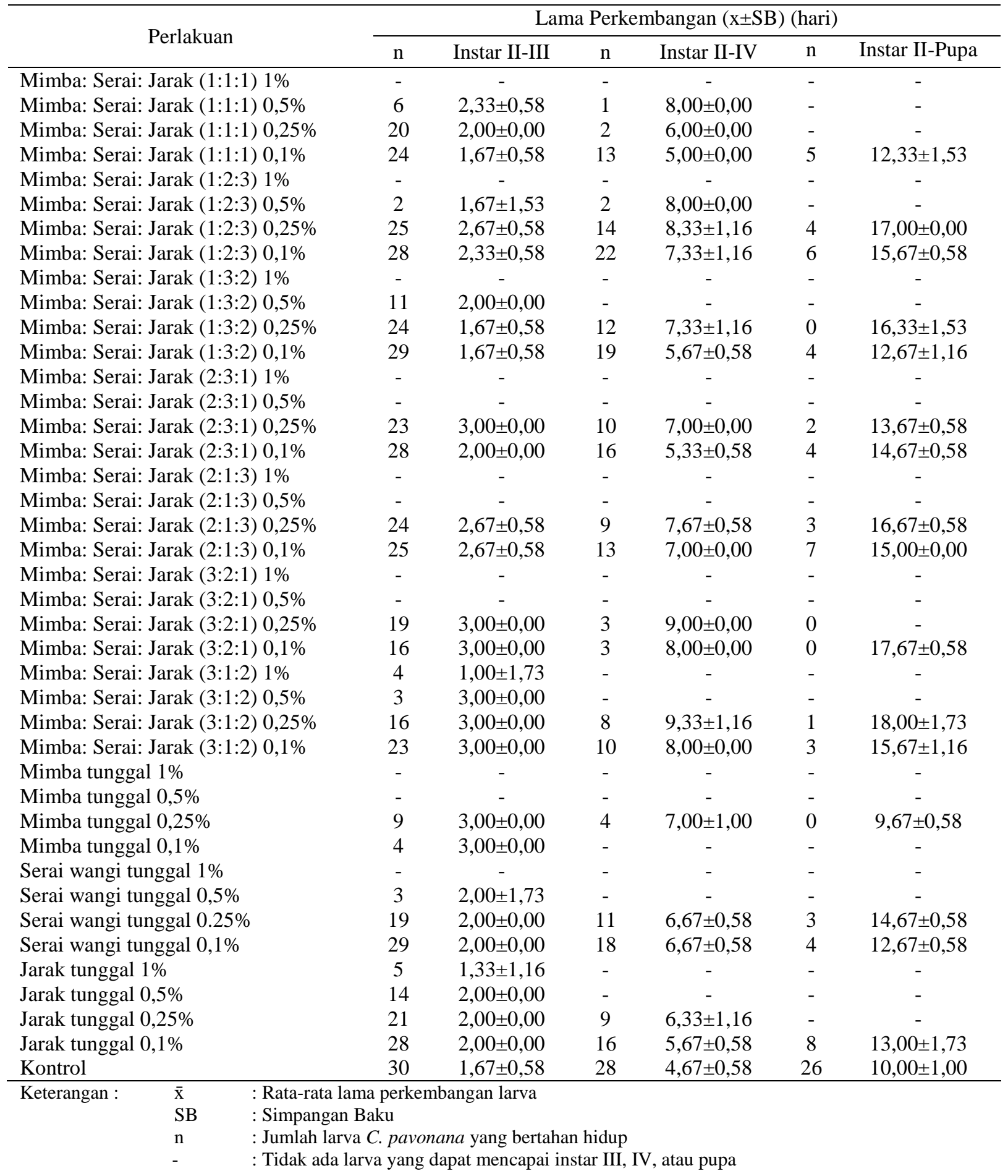


Tabel 3. Bobot larva instar IV, pupasi (\%) dan bobot pupa C. pavonana (gram)

\begin{tabular}{|c|c|c|c|c|c|}
\hline Perlakuan & $\begin{array}{c}\text { Bobot Larva } \\
\overline{\mathrm{x}} \pm \mathrm{SB}(\mathrm{g})\end{array}$ & $\mathrm{n}^{1}$ & $\begin{array}{c}\text { Pupasi } \\
(\%)\end{array}$ & $n^{2}$ & $\begin{array}{c}\text { Bobot Pupa } \\
\overline{\mathrm{X}} \pm \mathrm{SB}(\mathrm{g})\end{array}$ \\
\hline Mimba: Serai: Jarak (1:1:1) 1\% & - & - & - & - & - \\
\hline Mimba: Serai: Jarak (1:1:1) 0,5\% & $0,005 \pm 0,009$ & 1 & - & - & - \\
\hline Mimba: Serai: Jarak (1:1:1) 0,25\% & $0,014 \pm 0,012$ & 2 & - & - & - \\
\hline Mimba: Serai: Jarak (1:1:1) $0,1 \%$ & $0,032 \pm 0,001$ & 13 & 16,67 & 5 & $0,031 \pm 0,027$ \\
\hline Mimba: Serai: Jarak (1:2:3) 1\% & - & - & - & - & - \\
\hline Mimba: Serai: Jarak $(1: 2: 3) 0,5 \%$ & $0,005 \pm 0,008$ & 2 & - & - & - \\
\hline Mimba: Serai: Jarak (1:2:3) 0,25\% & $0,020 \pm 0,001$ & 14 & 13,33 & 4 & $0,028 \pm 0,025$ \\
\hline Mimba: Serai: Jarak (1:2:3) 0,1\% & $0,038 \pm 0,002$ & 22 & 20 & 6 & $0,031 \pm 0,027$ \\
\hline Mimba: Serai: Jarak (1:3:2) 1\% & - & - & - & - & - \\
\hline Mimba: Serai: Jarak (1:3:2) 0,5\% & - & - & - & - & - \\
\hline Mimba: Serai: Jarak $(1: 3: 2) \quad 0,25 \%$ & $0,009 \pm 0,016$ & 12 & - & - & - \\
\hline Mimba: Serai: Jarak (1:3:2) 0,1\% & $0,029 \pm 0,003$ & 19 & 13,33 & 4 & $0,041 \pm 0,004$ \\
\hline Mimba: Serai: Jarak (2:3:1) 1\% & - & - & - & - & - \\
\hline Mimba: Serai: Jarak (2:3:1) $0,5 \%$ & $0,005 \pm 0,008$ & - & - & - & - \\
\hline Mimba: Serai: Jarak $(2: 3: 1)$ 0,25\% & $0,021 \pm 0,001$ & 10 & 6,67 & 2 & $0,018 \pm 0,024$ \\
\hline Mimba: Serai: Jarak (2:3:1) 0,1\% & $0,015 \pm 0,013$ & 16 & 13,33 & 4 & $0,039 \pm 0,004$ \\
\hline Mimba: Serai: Jarak (2:1:3) 1\% & - & - & - & - & - \\
\hline Mimba: Serai: Jarak (2:1:3) 0,5\% & - & - & - & - & - \\
\hline Mimba: Serai: Jarak (2:1:3) $0,25 \%$ & $0,023 \pm 0,006$ & 9 & 10 & 3 & $0,039 \pm 0,005$ \\
\hline Mimba: Serai: Jarak (2:1:3) 0,1\% & $0,039 \pm 0,002$ & 13 & 23,33 & 7 & $0,040 \pm 0,014$ \\
\hline Mimba: Serai: Jarak (3:2:1) 1\% & - & - & - & - & - \\
\hline Mimba: Serai: Jarak (3:2:1) 0,5\% & - & - & - & - & - \\
\hline Mimba: Serai: Jarak $(3: 2: 1) 0,25 \%$ & $0,009 \pm 0,016$ & 3 & - & - & - \\
\hline Mimba: Serai: Jarak $(3: 2: 1) 0,1 \%$ & $0,011 \pm 0,019$ & 3 & - & - & - \\
\hline Mimba: Serai: Jarak (3:1:2) 1\% & - & 1 & - & - & - \\
\hline Mimba: Serai: Jarak (3:1:2) 0,5\% & $0,004 \pm 0,008$ & 1 & - & - & - \\
\hline Mimba: Serai: Jarak (3:1:2) 0,25\% & $0,018 \pm 0,001$ & 8 & 3.33 & 1 & $0,016 \pm 0,029$ \\
\hline Mimba: Serai: Jarak (3:1:2) 0,1\% & $0,026 \pm 0,001$ & 10 & 10 & 3 & $0,040 \pm 0,014$ \\
\hline Mimba tunggal $1 \%$ & - & - & - & - & - \\
\hline Mimba tunggal $0,5 \%$ & - & - & - & - & - \\
\hline Mimba tunggal $0,25 \%$ & $0,006 \pm 0,010$ & 4 & - & - & - \\
\hline Mimba tunggal $0,1 \%$ & - & - & - & - & - \\
\hline Serai wangi tunggal $1 \%$ & - & - & - & - & - \\
\hline Serai wangi tunggal $0,5 \%$ & - & - & - & - & - \\
\hline Serai wangi tunggal $0,25 \%$ & $0,019 \pm 0,017$ & 11 & 10 & 3 & $0,028 \pm 0,025$ \\
\hline Serai wangi tunggal $0,1 \%$ & $0,038 \pm 0,002$ & 18 & 13.33 & 4 & $0,045 \pm 0,003$ \\
\hline Jarak tunggal $1 \%$ & - & - & - & - & - \\
\hline Jarak tunggal $0,5 \%$ & - & - & - & - & - \\
\hline Jarak tunggal $0,25 \%$ & $0,035 \pm 0,000$ & 9 & - & - & - \\
\hline Jarak tunggal $0,1 \%$ & $0,036 \pm 0,001$ & 16 & $26 ., 7$ & 8 & $0,042 \pm 0,002$ \\
\hline Kontrol & $0,045 \pm 0,002$ & 28 & 86,67 & 26 & $0,051 \pm 0,001$ \\
\hline \multicolumn{6}{|c|}{$\begin{array}{lcl}\text { Keterangan: } & \overline{\mathrm{x}}: \text { Rata-rata bobot larva atau pupa }(\mathrm{g}) \\
& \mathrm{SB}: \text { Simpangan Baku } \\
& \mathrm{n}^{1}: \text { Jumlah larva yang bertahan hidup hingga instar IV } \\
& \mathrm{n}^{2}: \text { Jumlah Pupa } \\
& -\quad: \text { Tidak ada larva yang mencapai instar IV atau pupa }\end{array}$} \\
\hline
\end{tabular}




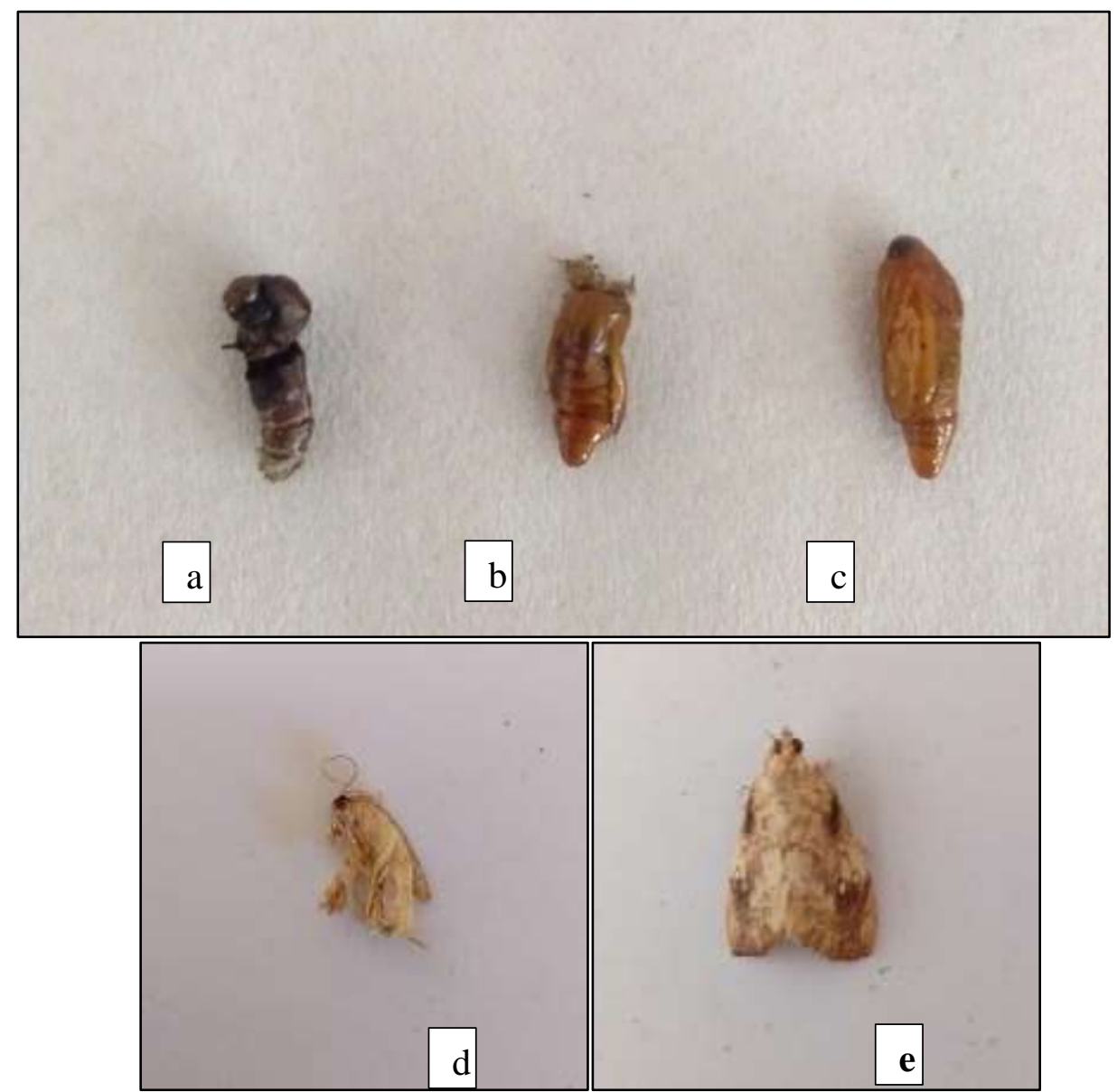

Gambar 3. Pengaruh perlakuan minyak terhadap perkembangan larva dan pupa C. pavonana. (a) Larva yang gagal membentuk pupa, (b) Pupa abnormal, (c) Pupa normal, (d) Imago abnormal, (e) Imago normal

\section{KESIMPULAN}

Perlakuan campuran minyak mimba, serai wangi, dan jarak dengan rasio 3:2:1 merupakan kombinasi tearbaik dalam mengakibatkan kematian larva Crocidolomia pavonana. Perlakuan campuran dengan rasio 3:2:1 tersebut pada konsentrasi 0,25\% mengakibatkan penghambatan perkembangan larva dan menurunkan bobot pupa, serta rasio 3:1:2 pada konsentrasi 0,5\% mampu menurunkan bobot larva.

\section{ACKNOWLEDGEMENT}

Penelitian ini merupakan bagian dari payung penelitian dengan tema "Pengembangan Formulasi insektisida Nabati: Peningkatan Bioaktivitas Berbasis Campuran Bahan Nabati" dengan peneliti utama Danar Dono.

\section{DAFTAR PUSTAKA}

Ahadian, F., N. Ginting, T. H. Wahyuni, \& Anwar. 2010. Efektivitas skabisida ekstrak daun mimba (Azadirachta Indica A. Juss) terhadap tungau Sarcoptes scabiei secara in vitro. Jurnal Peternakan Integratif. 1(1):1-10.

Ahdiyah, I., \& K. I. Purwani. 2015. Pengaruh Ekstrak Daun Mangkokan (Nothopanax cutellarium) sebagai Larvasida Nyamuk Culex Sp. Jurnal Sains dan Seni ITS. 4(2): 2337-3520.
Atkins, M. D. 1980 Introduction to Insect Behaviour Mac Millan Publ. Co. Inc. Newyork.

Balfas, R. \& T. L. Mardiningsih. 2016. Pengaruh minyak atsiri terhadap mortalitas dan penghambatan peneluran Crocidolomia Pavanana F. Buletin Litro. 27 (1): 85-92.

Cheng, J., Z. T. Wu, L. Liu, W. Yang, \& L. He. 2014. EcR-RNAi and azadirachtin treatments induced the abnormal proleg development in Spodoptera litura. Journal of East China, Normal University. 1: 133-142.

Dadang \& D. Prijono. 2008. Insektisida Nabati: Prinsip, Pemanfaatan, dan Pengembangan. Departemen Proteksi Tanaman, Institut Pertanian Bogor, Bogor.

Dono, D., S. Ishmayana, Idar, D. Prijono, \& I. Muslikha. 2010. Status dan Mekanisme Resistensi Biokimia Crocidolomia pavonana (F.) (Lepidoptera: Crambidae) terhadap Insektisida Organofosfat serta Kepekaannya terhadap Insektisida Botani Ekstrak Biji Barringtonia asiatica. Jurnal Entomologi Indonesia. 7(1): 9-27.

Frigerio, L. \& L.M. Roberts. 1998. The enemy within: ricin and plant cells. Journal of Experimental Botany, 49 (326): 1473-1480. 
Fujiarista, F. H. 2019. Pengaruh campuran ekstrak biji mimba (Azadirachta indica A. Juss) dan serai wagi (Cymbopogon nardus L.) terhadap ulat krop kubis (Crocidolomia pavonana (F.)). Skripsi. Jurusan Hama dan Penyakit Tumbuhan Fakultas Pertanian Unpad.

Hasyim, A., W. Setiawati, R. Murtiningsih, \& E. Sofiari. 2010. Efikasi dan Persistensi Minyak serai sebagai biopestisida terhadap Helicoverpa armigera Hubn. (Lepidoptera: Noctuidae). Jurnal Hortikultura. 20(4): 337386.

Indiati \& S.W. Marwoto. 2008. Potensi ekstrak biji mimba sebagai insektisida nabati. Buletin Palawija. 15: 9-14.

Isman, M.B. 2006. Botanical insecticides, deterrents, and repellents inmodern agriculture and an increasingly regulatedworld. Annu. Rev. Entomol. 2006. 51:45-66. DOI: 10.1146/annurev.ento.51.110104.151146

Isman, M.,B., O. Koul, A. Luczynski, \& J. Kaminskis. 1990. Insecticidal and Antifeedant

Bioactivities of Neem Oils and Their Relationship to Azadirachtin Content. J. Agric. Food Chem. 38: 1406-1411.

Kodjo, T. A., M. Bénonchi, A. Sadate, A. Komi, G. Y. M. Dieudonné, \& S. Komla .2011. Bioinsecticidal effects of plant extracts and oil emulsions of Ricinus communis $L$. (Malpighiales: Euphorbiaceae) on the diamondback, Plutella xylostella L. (Lepidoptera: Plutellidae) under laboratory and semi-field conditions. Journal of Applied Biosciences, 43: $2899-2914$.

Nailufar, N., \& D. Prijono. 2017. Synergistic activity of Piper aduncum fruit and Tephrosia vogelii leaf extracts against the cabbage headcaterpillar, Crocidolomia pavonana. J. ISSAAS. 23(1): 102-110.

Pinheiro, P.F., V.T. de Queiroz, V.M. Rondelli, A.V. Costa, T. de P. Marcelino, D. Pratissoli. 2013. Insecticidal Activity Of Citronella Grass Essential Oil On Frankliniella schultzei AND Myzus persicae. Ciênc. agrotec., Lavras, 37 (2): 138-144.

Pinheiro, P.V., \& E.D. Quintela (2010). Neem Oil Antifeedant And Insecticidal Effects on Oebalus poecilus (Hemiptera: Pentatomidae) Males And Females. Pesq. Agropec. Trop. 40 (4): 394-400, DOI: 10.1590/s198340632010000400018.

Ramos-López, M. A., S. Pérez G., C. RodríguezHernández, P. Guevara-Fefer, \& M. A. Zavala-Sánchez. 2010. Activity of Ricinus communis (Euphorbiaceae) against Spodoptera frugiperda (Lepidoptera: Noctuidae). African Journal of Biotechnology, 9(9): 1359-1365,

Sahayaraj, K., M. Venkateshwari, \& R. Balasubramanian. 2008. Insecticidal and
Antifeedant Effect of Pedalium murex Linn. Root on Spodoptera litura (fab) (Lepidoptera: Noctuidae). J. of Agric. Technol. 4(2): 73-80.

Samsudin. 2011. Biosintesa dan cara kerja azadirachtin sebagai bahan aktif insektisida nabati. Balai Penelitian Tanaman Rempah dan Aneka Tanaman Industri. Prosiding Seminar Nasional Pestisida Nabati IV: 6170.

Sayuthi, M., Hasnah, \& S. Jannah. 2014. Ekstrak daun papaya dan biji jarak kepyar berpotensi sebagai insektisida terhadap hama Crocidolomia pavonana (Lepidoptera: Pyralidae) pada tanaman brokoli. Jurnal Biologi Edukasi. 6(2): 78-82.

Shahidi-Noghabi, S., E.J.M. van Damme, \& G. Smagghe, (2009). Expressionof Sambucus nigra agglutinin (SNA-I') from elderberry bark in transgenic tobacco plants results in enhanced resistance to different insect species. Transgenic Res. 18, 249-259. doi:10.1007/s11248-008-9215-2

Sharma, S., A. Senrung, \& A. K. Singh. 2014. Toxic effect of neem, Azadirachta indica (A. Juss) foliage extracts against diamondback moth (DBM), Plutella xylostella (L.) (Lepidoptera, Plutellidae). JBiopest. 7: 99-105.

Subiyakto. 2009. Ekstrak biji mimba sebagai pestisida nabati: potensi, kendala, dan strategi pengembangannya. Jurnal Perspektif, Vol. 8(2): 108-116.

Suyanto A. \& A. Manan. 2011. Ekstrak biji nimba Azadirachta indica A. Juss pengaruhnya terhadap peletakan dan penetasan telur ulat hati kubis Crocidolomia pavonana F. LPPM Journal. 11(1):1-6.

Syahputra, E. 2013. Insecticidal Activities of Barringtonia sarcostachys bark Extract Against Cabbage Head Caterpillar Crocidolomia Pavonana (F.). J. ISSAAS 19 (2): 8-17.

Syahroni, Y.Y. \& D. Prijono. 2013. Aktivitas insektisida campuran ekstrak buah Piper aduncum (Piperaceae) dan Sapindus rarak (Sapindaceae) terhadap larva Crocidolomia pavonana. J. Entomol. Indones. 10(1): 39-50.

Tukimin, S.W., D. Soetopo \& E. Karmawati. 2010. Pengaruh Minyak Jarak Pagar (Jatropha curcas L.) Terhadap Mortalitas, Berat Pupa, Dan Penularan Hama Jarak Kepyar. Jurnal Littri. 16(4): 159-164.

Wei, G.Q., R.S. Liu, Q. Wang, \& W.Y. Liu. 2004. Toxicity of two type II ribosome-inactivating proteins (cinnamomin and ricin) to domestic silk worm larvae. Arch. Insect Biochem. Physiol. 57, 160-165. doi:10.1002/arch.20024.

Widayani, N. S., A N. Haq, L. T. Puspasari, Y. Hidayat, \& D. Dono. 2018. Effect of 
temperature, storage time, the residual test of neem oil formulation (Azadirachta indica A. Juss) and bitung formulation (Barringtonia asiatica) to its toxicity against large cabbage heart caterpillar (Crocidolomia pavonana $\mathrm{F}$ ). Jurnal Cropsaver. 1(1): 27-36.

Wiranda, J. 2019. Toksisitas campuran minyak mimba (Azadirachta indica A. Juss) dan minyak biji jarak (Riccinus communis L.) terhadap ulat krop kubis (Crocidolomia pavonana (F.)). Skripsi. Jurusan Hama dan Penyakit Tumbuhan Fakultas Pertanian Unpad.

Zahro, F. A., T. Himawan, \& G. Mudjiono. 2016. Uji bioaktivitas ekstrak daun serai wangi (Cymbopogon nardus L. Rendle) terhadap Plutella xylostella Linnaeus. Jurnal HPT. 4(2): 86-92. 